\title{
Project-Based Learning as a Tool of Enhancing of Entrepreneurial Attitude of Students
}

\author{
Dana Pal'ová*,1, Martin Vejačka ${ }^{1}$, Lukáš Kakalejčík ${ }^{2}$ \\ ${ }^{1}$ Department of Applied Mathematics and Business Informatics, Faculty of Economics, Technical University of Košice, 04001, \\ Slovakia \\ ${ }^{2}$ GrowthPro, Košice, 04001 Slovakia
}

\begin{tabular}{l} 
A R T I C L E I N F O \\
\hline Article history: \\
Received: 06 December, 2019 \\
Accepted: 13 January, 2020 \\
Online: 07 February, 2020
\end{tabular}

Keywords:

Entrepreneurial education

Project-Based Learning

Virtual laboratory

Europe 2020

\begin{abstract}
A B S T R A C T
The increase in employment and productivity is crucial for the economic growth of the European Union. Specifically, the employment of young people needs to be increased. The excessively theoretical approach to education is identified as one of the most significant problems in the educational system. Acquirement of practical experience while study, presents for the students the advantage when applying for a job or starting their own business. Self-employment or entrepreneurship might be one of the partial solutions for high youth unemployment in EU countries. The information and communication technologies transform education processes already for decades. The education in the area of entrepreneurship is also the field where these transformations occur. New educational forms and tools are being used in this area. Project-Based Learning and virtual laboratory are two examples of such new forms of education supported by information and communication technologies used in entrepreneurial education. This paper aims to present how project-based learning and virtual laboratory can support entrepreneurial education on the examples of two courses offered at our faculty. Through project-based learning, participants of these courses achieve the opportunity to implement their knowledge, skills, and experience to solve practical problems. It, all together, enhances the students' motivation and involvement in the educational process. They also practical experience establishing and managing a small virtual business within the virtual laboratory of entrepreneurial education. The paper describes the setup of these courses, their content, and evaluation by students and achieved results. The findings show that project-based learning and the virtual lab supporting entrepreneurship education via electronic tools are useful ways of entrepreneurial skills development.
\end{abstract}

\section{Introduction}

This paper is an extension of work originally presented in MIPRO 2019 [1]. The creation of new businesses always supported the economic growth of the economy [2]. Education in the field of entrepreneurship and enhancing the entrepreneurial attitude of students should be an important part of the curricula of universities with majors in economics and business management. However, in Slovakia, universities in the economics study plans usually prepare their students for the role of employees not for the role of entrepreneurs.

\footnotetext{
* Dana Pal'ová, Faculty of Economics, Technical University of Košice, Nemcovej 32, 04001, Slovakia, +421556023268, dana.palova@tuke.sk
}

Harris [3] adduced that education often does not provide practical experience with real-world entrepreneurship. On the other hand, the time during the studies at the university could be an ideal time to start-up student's business, while they have the opportunity to practically learn, cooperate with or employ their classmates allowing them to gain work experience. At the same time, the support of the student's family in the case of business failure can be counted as one of the biggest benefits. Furthermore, a lot of successful businesses occur after multiple business failures [4]. In addition, failed enterprise brings valuable experience for involved entrepreneurs, which can be used in their future careers (both as entrepreneurs or employees). Information and communication technologies (ICT) influenced the world of business in many ways. It is currently common, that ICTs are used 


\section{Pal'ová et al. / Advances in Science, Technology and Engineering Systems Journal Vol. 5, No. 1, $346-354$ (2020)}

for setting up the businesses, for promoting and distributing products, for using the banking services or for communication with authorities. The impact of ICT was also reflected in the emergence and use of electronic commerce (or e-commerce) as a still-growing distribution and marketing channel [5].

Therefore, entrepreneurship courses set up and provided at our university aim to provide the opportunity to gain practical experience with entrepreneurship for our students.

\section{Theoretical Background}

\subsection{Entrepreneurship and unemployment of the young generation in the context of European Union growth and sustainability}

Youth unemployment is one of the key economic problems in multiple EU economies. In 2018 the youth unemployment was over 15 percent in the European Union, which is higher in comparison with other productive groups of citizens [6]. One of the possible solutions on how to reduce the youth unemployment rate might be the support of their self-employment ambitions by fostering the entrepreneurial spirit in the education process. Entrepreneurship supports personal development, encourages active participation in a community or society, and teaches a person how to enter or reenter the job market as a self-employed person or an employee.

The Europe 2020 strategy urges to promote economic growth and competitiveness via innovation [7]. Entrepreneurship in innovative fields might help to achieve its goals. The individual's ability to turn ideas into action, the activity aimed at achieving the business goals and the implementation of innovation and creativity are the main characteristics of the entrepreneurship itself [8]. New Skills Agenda for Europe [9] promotes the development of the entrepreneurial skills in the Entrepreneurship Competence Framework (Entrecomp) [10]. EntreComp defines entrepreneurship as an ability necessary in the $21^{\text {st }}$ century, including social, managerial, technical, cognitive and relational skills. McCorkle et al. [11] also indicate these skills as important for entrepreneurs. Wiklund and Dean [12] include also creativity as a crucial entrepreneurial skill. Table 1 (bellow) illustrates EntreComp Framework and its main parts visualization.

Table 1: EntreComp Framework

\begin{tabular}{|l|ll|}
\hline \multicolumn{1}{|c|}{ Key Area } & \multicolumn{1}{|c|}{ Competency } \\
\hline Ideas & - & Spotting Opportunities \\
and Opportunities & - & Creativity \\
& - & Vision \\
& - & Valuing Ideas \\
& - & Ethical and Sustainable Thinking \\
\hline Resources & - & Motivation and Perseverance \\
& - & Self Awareness and Self Efficacy \\
& - & Financial and Economic Literacy \\
& - & Mobilizing Others \\
& - & Mobilizing Resources \\
\hline Into Action & - & Learning Through Experience \\
& - & Working with Others \\
& - & Planning and Management \\
& - & Taking the Initiative \\
& - & Coping with Ambiguity, Uncertainty and \\
& & Risk \\
\hline
\end{tabular}

\subsection{Education towards innovative entrepreneurship}

When starting a new business, entrepreneurial skills are very important. To know how to reduce business risks, to know how to use the creativity tools, to know how to learn from the market and to know-how to innovate are the key competencies in the realization of a new business idea [13]. Some of the main entrepreneurial skills for successful entrepreneurship were described by the Institute of Entrepreneurship Development [14]:

- Creating a business plan and planning in general together with the access to financing are crucial factors for business sustainability.

- Communication and networking skills_to clearly express ideas and create relationships with people within and outside the organization.

- Leadership and managerial skills covering skills for the ability to plan organizational activities, coordination and motivation of human resources and developing cooperation and team-work, communicating the vision of the business and its objectives, etc.

- Digital marketing skills to boost competitiveness, innovation, and productivity. These skills include the know-how in the usage of digital tools and technologies for business growth on the market.

\subsection{Project-Based Learning method (PBL) in Education of 21st Century}

The current generation of students was born into a world of ubiquitous Information and Communication Technologies (ICT). Therefore, it is natural for them to use ICT in every aspect of their lives, including education. Brown [15] stated that for digital youth, ICTs are an integral part of their social life, which changes their perception of life, behavior, and education. Also, their requirements on the educational process, design and content are influenced by their attitude towards ICT. Millennials spend on average 6.5 hours using ICT for different purposes (e.g. listen to and record music; view, create and publish Internet content; play video games; watch television; talk on mobile phones and instant message) [16]. They can be described by the following attributes: group-oriented, global, technologically confident, risk-taking and optimistic. Taking into account the above-mentioned facts, the International Education Advisory Board [17] defined main requirements on new learning design as following (Table 2):

Table 2: Requirements on 21st-century learning design

\begin{tabular}{|l|l|}
\hline \multicolumn{1}{|c|}{ Requirements } & \multicolumn{1}{c|}{ Learning design } \\
\hline goals & $\begin{array}{l}\text { Learning objectives are clear - the teacher must } \\
\text { define in advance clear, realistic, reachable } \\
\text { conditions for the successful accomplishment of } \\
\text { the learning process. The main idea is that } \\
\text { everybody has the same criteria for passing, it } \\
\text { doesn't matter on the way, speed and time } \\
\text { needed to complete the objectives. }\end{array}$ \\
\hline Patience & $\begin{array}{l}\text { Students may redo assignments repeatedly if } \\
\text { necessary. It is important to give a chance to try } \\
\text { it more times until the students are finally } \\
\text { successful. The Millenials are prepared to learn } \\
\text { from their mistakes and they will try to do the } \\
\text { task again and again. }\end{array}$ \\
\hline Team play & $\begin{array}{l}\text { Tasks are completed, evaluated and reviewed by } \\
\text { the groups of students. Using this way, the } \\
\text { learners achieve the possibility to introduce } \\
\text { themselves, to identify their strong and weak } \\
\text { characteristics and discover their uniqueness } \\
\text { and individuality. }\end{array}$ \\
\hline Tracking & $\begin{array}{l}\text { Students could see their progress at any time } \\
\text { and any particular education process level and }\end{array}$ \\
\hline
\end{tabular}


D. Pal'ová et al. / Advances in Science, Technology and Engineering Systems Journal Vol. 5, No. 1, 346-354 (2020)

\begin{tabular}{|l|l|}
\hline \multicolumn{1}{|c|}{ Requirements } & \multicolumn{1}{|c|}{ Learning design } \\
\hline Change & $\begin{array}{l}\text { also as a whole. It allows them to control their } \\
\text { path to reach the learning objectives. }\end{array}$ \\
\hline $\begin{array}{l}\text { Students are learning time management and } \\
\text { how to progress towards (achieving) the goal by } \\
\text { dividing the large tasks. At the same time, they } \\
\text { can learn how the task division moves a project } \\
\text { along. }\end{array}$ \\
\hline Pensequences & $\begin{array}{l}\text { Teachers provide immediate/useful feedback } \\
\text { and meaningful, formative and diagnostic } \\
\text { assessments. It helps students to identify, what } \\
\text { works for them and what does not in an easier } \\
\text { way. }\end{array}$ \\
\hline Patterns & $\begin{array}{l}\text { Students can discover their strengths and reach } \\
\text { the learning objectives by playing different } \\
\text { roles. }\end{array}$ \\
\hline $\begin{array}{l}\text { The learning environment makes sense for the } \\
\text { students. By learning to identify patterns and } \\
\text { make logical decisions during the education } \\
\text { process the environment helps students cultivate } \\
\text { higher-level thinking skills. }\end{array}$ \\
\hline
\end{tabular}

Source: [17]

The project-based learning (PBL) might be one of the methods suitable for teaching this new generation of digitally native students. The Gold Standard of project-based learning (Figure 1) introduced by [18] includes also other skills such as self-reflection, critical thinking, research and inquiry skills.

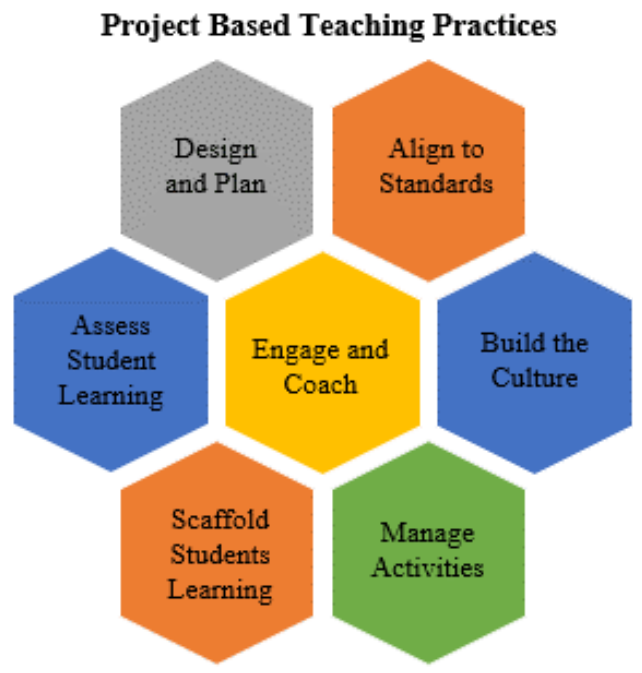

Figure 1: Key Knowledge, understanding and success skills enhanced by Gold Standard PBL; source: [18]

Project-Based Learning includes the personalization of learning for students [19]. PBL is student-directed learning that requires students to work on real-world projects over a specific period. During this time, they have to present and implement different knowledge and skills. Therefore, students find out that obtained skills and knowledge can be used in the practice [20].

While using PBL methods, lecturers could create collaborative groups of students to encourage the learning of students, as they have to face the same difficulties together [21]. The learning process then includes the utilization of the prior knowledge and information and promotes discussion in the students' groups. This leads to a higher interest of students in the educational process [22].

While using Project-Based Learning, the project solved should meet the following points:
- Authenticity - the project should be an authentic problem solved by using real tools, processes, and standards. The main principle is, that project needs to speak to personal concerns, interests, and issues of particular student.

- Challenging Problem or Question - makes learning more meaningful for students as they have to apply a lot of their knowledge and skills to find a solution to the problem.

- Sustained Inquiry - as students' colleagues or lecturers constantly confront their achieved results, the searching for necessary information is more dynamic and interactive. This inquiry might include interviews with experts, future customers, etc.

- Student Voice and Choice - students receive only project definition, but the methods of the project's working-out depend on students' choice.

- Reflection - supports what students have learned and encourages them to imagine how it could be applied elsewhere - outside the project. Teacher together with the students reflects the quality of student work, obstacles that arise and together try to find the problem overcoming strategies.

- Revision and Critique - show how to receive (and also give) constructive feedback during the project development (thanks to that students get experience how it runs in real life). Experts from practice or classmates might be involved in a critique.

- Public Product - increases motivation to higher quality work of students, because they are afraid of possible negative feedback on their results' presentation before the audience consisting of their classmates [18].

Project-Based Learning might support creativity amongst the students and teachers. Furthermore, students deepen the context of their knowledge and develop communication skills and critical thinking as they are doing an authentic project [23].

\subsection{Meaning of the virtual laboratory in modern education}

Currently, one of the crucial factors influencing the competitiveness and survival of the business on the marketplace is the rate of effective exploitation of ICT. The entrepreneurs must be able to keep track of a huge amount of information and available tools and to determine its possible implementation to their business area. This fact points to the need to integrate ICT into the entrepreneurial education process. The use of information and communication technologies in education may have many forms and various intensity.

The use of a virtual laboratory for entrepreneurial education is rather new. The intensive ICT involvement in teaching and learning process could be represented by the virtual laboratory. The concept of the virtual laboratory could be described in general as an environment of various cooperating ICT systems enabling the simulation of some real-world activity [24]. The usage of the virtual laboratory in entrepreneurship education might provide real-market experience for students in a very cost-effective way. Klamma et al. stated that a virtual laboratory might be very effective in ICT usage in entrepreneurial education [24].

Typically, the virtual laboratory is considered to be an interactive environment for carrying out simulated experiments. 


\section{Pal'ová et al. / Advances in Science, Technology and Engineering Systems Journal Vol. 5, No. 1, $346-354$ (2020)}

The laboratory can be characterized as "a playground for experimentation" providing tools that can be used to manipulate objects relevant to a specific scientific domain. This concept is relevant for both, conventional and virtual laboratories. However, there is an important distinction in terminology, where a virtual laboratory is often custom-built to perform a limited set of experiments [25].

Task of design and development of the virtual laboratory for the education is highly complex. It covers the need of the set of the skills from various areas such as pedagogy, design and visualization. This process involves also the development of texts, images, learning environments and their interactions [25]. The development of the virtual laboratory and it's implementing in the teaching process, builds up the knowledge in technology, pedagogy and content knowledge [26].

Bretz et al. [27] indicated that involving virtual laboratories to the education process brings many advantages. It helps students to understand deeper science concepts, to develop their ability to identify, evaluate and solve different kinds of problems [28]. Moreover using virtual laboratories increases students' curiosity and grows up their motivation to take part in the education actively [29].

Virtual laboratories are becoming an increasingly common tool for teaching [30]. However, this is true, especially for the fields of physics, chemistry, and biology [31]. It is very often used for entrepreneurial education because it has significant potential in this area [24]. Often, the virtual laboratory in the field of entrepreneurial education is implemented differently than in the natural sciences, where it frequently represents virtual reality simulation of a lab. When used in entrepreneurial education, the virtual laboratory more likely simulates the functionality of various parts of the economy, a firm or a firm's lifecycle. The examples of simulated objects might be business registration or interaction with the public administration authorities, payment systems, market mechanisms, online marketing tools, and many others. This brings great possibilities of gaining valuable experience for the students without the necessity of great expenses spent on running a real business and involving virtual laboratory in that field supports meaningful learning by linking the previous information with a new one [32].

\section{Courses supporting Entrepreneurial Education}

All startups face great challenges when trying to grip on the market and up to $90 \%$ will fail to survive [33]. Da Silva et al. [34] adduced pricing issues, market validation and ignorance of customers' demands as main problems causing startup failures. Wang et al. [35] confirmed the fitting of the products on the market as an important problem of the startups adding also the functionality of the business model and issues with the acquisition of customers. Giardino et al. [36] also included targeting toospecialized markets to the list of significant issues of startups causing their failure. In consideration of these facts, the education process of the future entrepreneurs should help them to prevent such issues.

Furthermore, mastering ICT usage is currently a crucial element of entrepreneurial success. Entrepreneurial education should reflect the reality and the usage of ICTs as the most innovative and beneficial for students. McCorkle et al. [11] stated that students studying marketing and entrepreneurial education need space for creativity, what traditional education usually limits.
The overview of Granitz and Pitt [37] summarized several unusual technology tools to teach entrepreneurship and marketing.

Resulting from the research in entrepreneurial and marketing education carried out, two new university courses were introduced. The courses should allow to apply students' knowledge in entrepreneurship (and in marketing as its organic element) and acquire practical skills in real conditions with the help of modern ICT tools. The above mentioned PBL method widely supported by various ICT tools was used to develop the content of the courses.

The education towards entrepreneurship is more-less covered by most of the subjects learned at the Faculty of Economics. During their studies, students are educated in theoretical fields like management, company finance, accounting, legislation, etc. This theoretical knowledge is important to achieve, but it cannot be denoted as the engine of students' curiosity and self-involvement in their study process. That is why it is really important to provide subjects that provide them more practical insight into the "real" world of the business and entrepreneurship. This is the reason why we developed innovative courses "Marketing Tools for the Presentation and Evaluation of Business Ideas" and "Economic Information Systems". In the mentioned courses, students are led to go through almost all levels of the entrepreneurial life cycle described in [38] and at the same time, they develop their skills defined in EntreComp, which are important for start-uppers and new entrepreneurs in general.

\subsection{The course: Marketing tools for the presentation and evaluation of business ideas}

The first course named "Marketing tools for the presentation and evaluation of business ideas" aims to concede practical education in the area of first steps in the entrepreneurial life cycle, for example, the introduction of new idea or product, and afterward company/corporate marketing. Within this course, students solve the practical problems of developing the product, fitting the product for the market, promotion, and analytics. This allows students to experience the start of the company from scratch widely supported by various ICT tools [1].

\section{AUTOHELPER} a

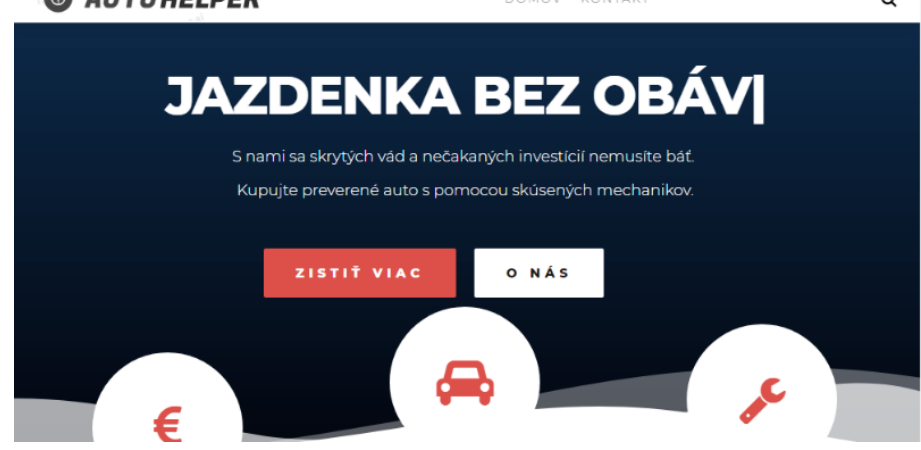

Figure 2: Final web-site of the service supporting sale of used cars; source: own based on students' web-site

The content of the course could be described as following: students should bring the business idea of product creation and then directly verify its market readiness and response. Students gain theoretical knowledge in the area of business models, key performance indicators, business objectives, web design, online marketing and its data analysis. When solving the practical problems, students obtain practical experience with social network marketing and applications such as Google Ads, Google Analytics, 
Google Trends, Google Tag Manager, Google Market Finder, WordPress, and others. To achieve the final goal, i.e. to make a decision about the competitiveness and sustainability of their product or service, students need to design a web page, which is used for collecting main data for the Google Analytics tool. Figure 2 and Figure 3 represents the preview of designed websites.

\section{WEAVER}

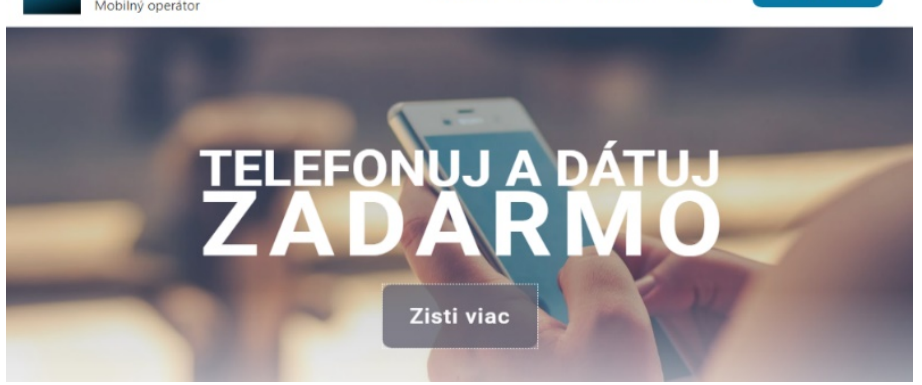

Figure 3: Final web-site of the service supporting the free call of a new service provider; source: own based on students' web-site

The course has two parts: face-to-face (F2F) part, where its content is dedicated to basic project management, various business models and their Key Performance Indicators, multiple types of marketing (email, social media, content marketing), web design, marketing research, and marketing data analysis and self-study part, where the LMS Moodle is used for publishing and management of the course materials, schedules, and activities. The acquired skills and knowledge are then used by the students during work on their projects. Students form small teams (2-5 people) and their roles in the team are assigned by themselves. The student teams present their business model, product, product's fit to market and marketing strategy. The team projects are evaluated by lecturers, people from outside (operating in the field of online marketing and web-page design) and other students with a focus on business model definition and objectives, web presentation, usage of the marketing tools, gathering of the relevant data and its analysis and product viability on the market.

\subsection{The course: Economic Information Systems}

The provision of products using information and communication technologies is in the world of the business closely bounded to business intelligence systems, interchange of electronic data or electronic payments. All of these are known as electronic commerce and it can provide important tools and services for different business' relations as business-to-business, business-to-customer or customer-to-customer relations [39].

From the point of view of entrepreneurial education, it seems to be important to present the main activities needed by the entrepreneurs in the area of electronic commerce, for example, communication with the public administration authorities to meet the legal obligations, use of e-banking and e-payments [40]. The above-mentioned activities, important during the first period of the enterprise's existence, represent the content of the second developed course "Economic Information System".

The main idea of this course could be described in Figure 4 .

The Virtual Lab itself is a part of e-course, which is providing students with various study materials, for example, information on how to manage a virtual firm from its establishment to the end of the first business year using ICT. The on-line course, operated by LMS Moodle, acts as the main source where all relevant information is collected. Students can find there most important dates and the description of the tasks needed to be done.

The virtual laboratory covers the following parts of electronic entrepreneurship: authorities of the business registration (providing social and health insurance registration, taxation, licensing, etc.), virtual e-shops (both retail and wholesale), virtual bank and other entities necessary during firms' life-cycle. Students establish their business after getting familiar with all the legislative requirements, therefore they need to follow the legislation of the Slovak Republic and prepare all necessary documents for establishing the business (e.g. deed of foundation, registration forms, licenses, etc.).

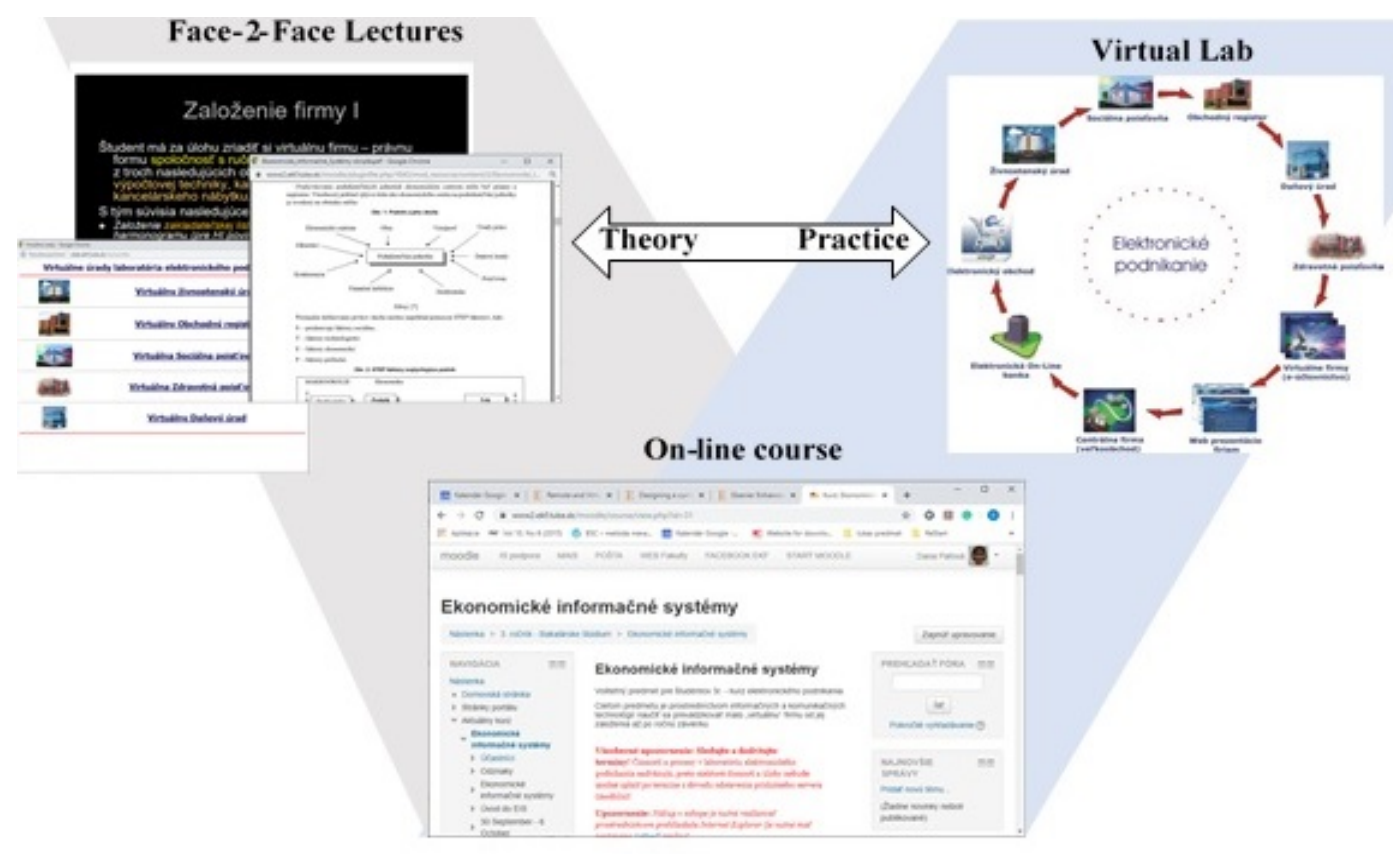




\section{Palová et al. / Advances in Science, Technology and Engineering Systems Journal Vol. 5, No. 1, 346-354 (2020)}

Afterward, they have to operate their own business using company website, e-shop. During the subject study, they act also as clients of businesses of their classmates. Using this principle, we can simulate the real market and students could achieve experience in pricing, sales and payments coordination. At the same time, students need to keep an accounting of their business and prepare the financial statements, which are bases for the final strategic study of their business. The results of the particular part of the course are evaluated by university staff - experts in particular fields, for example, accounting, legislation, information technologies, etc. To be able to provide all content of the course fully using e-way, different tools are involved within the virtual lab, such as EJBCA (the open-source PKI certification authority), Adobe Acrobat Reader DC $\mathbb{C}$, UNICOM Electronic Online Bank [5].

\section{Results and discussion}

The main objective of both described courses is to provide practical insight into the company's life-cycle to the students. Every course shows the different parts of the entrepreneurship. While the course "Marketing Tools for the Presentation and Evaluation of Business Ideas" covers the beginnings of the business - just from the idea appearance to a decision whether the product could survive on the marketplace, the course "Economic Information Systems" presents the process from real establishment of the company till first year anniversary. To be able to evaluate, whether our goal was achieved, both of the courses contain the evaluation of the students' skills and knowledge acquired and also the feedback, which is used to evaluate the content of the courses and way how they were provided.

Answering the electronic feedback questionnaire was last mandatory task for all course participants in both courses. Respondents (using the five-point Likert scale) should indicate the degree of agreement with the group of statements aimed at the quality and realization of particular parts of education process in the course. Gathered rates of agreement were presented in the form of percentages of agreement.

The course of "Marketing Tools for the Presentation and Evaluation of Business Ideas" is optional, what causes the number of enrolled students is usually lower than in the mandatory courses. The feedback and evaluation of students are gathered in each course iteration.

Students acquire the final evaluation of their performance at the end of the course with the maximum percentage of $100 \%$ in the total. Following table contains the results of students during the recent iteration of the course (Table 3):

Table 3: Mean values reached by students for specific parts of the projects

\begin{tabular}{|l|c|c|}
\hline \multicolumn{1}{|c|}{ The part of the project evaluated: } & $\begin{array}{c}\text { Maximum } \\
\text { value }\end{array}$ & Mean value \\
\hline Formulation of objectives & $10 \%$ & $8.5 \%$ \\
\hline Web design and its functionality & $15 \%$ & $13.5 \%$ \\
\hline Web analytics & $15 \%$ & $14 \%$ \\
\hline Content marketing & $15 \%$ & $11.5 \%$ \\
\hline Data Analysis & $10 \%$ & $9.75 \%$ \\
\hline Viability of product & $10 \%$ & $10 \%$ \\
\hline Presentation of the project & $25 \%$ & $25 \%$ \\
\hline
\end{tabular}

Source: own contribution

At least one member of each team had to achieve official Google certification in Google Analytics Fundamentals and all students' teams have to achieve Google Tag Manager Fundamentals certifications. More than half of the students participating in the course successfully achieved these certificates. The teams often struggled to clearly define business goals and to set up Google Analytics, which lead to the misinterpretation or insufficiency of collected data from online channels.

Furthermore, students had to answer the feedback questionnaire at the course's end. The summary of the questionnaire's results can be following:

- $53 \%$ strongly agreed and $47 \%$ of students agreed that the content of the course met their expectations.

- $54 \%$ of responding students stated as the most interesting the part of designing the web and its further development, the marketing part of the course was indicated by $13 \%$ of them and $33 \%$ did not have the favorite part of the course.

- Over $87 \%$ of students were satisfied with the educational style of the course, mainly they highlighted not obvious borderline between theoretical lectures and practical exercises. Overall, students evaluated the course as motivating and interesting.

- $87 \%$ of the respondents indicated the course as moderately difficult and $13 \%$ as very difficult.

- All students agreed that the acquired skills and knowledge during the course are applicable in entrepreneurial practice.

- All participants appreciated the necessity to use teamwork and creativity in the process of their course project development.

- All of the responding students confirmed that the completion of the course improved their understanding of the operation of the start-up.

- $93 \%$ of all students managed to assess the importance of the business idea.

- $87 \%$ of respondents indicated the improvement of their managerial and entrepreneurial skills.

During the EIS course, students can obtain a maximum evaluation of their performance at the level of $100 \%$ at the end of the course. The following table contains their results during the recent iteration of the course (Table 4):

Table 4: Mean values reached by students for specific parts of the course

\begin{tabular}{|l|c|c|}
\hline \multicolumn{1}{|c|}{ The part of the course evaluated: } & $\begin{array}{c}\text { Maximum } \\
\text { value }\end{array}$ & $\begin{array}{c}\text { Mean value } \\
\text { reached }\end{array}$ \\
\hline $\begin{array}{l}\text { Establishing a company according to } \\
\text { legislation requirements }\end{array}$ & $20 \%$ & $18.13 \%$ \\
\hline Business plan preparation & $15 \%$ & 12.58 \\
\hline Website preparation & $10 \%$ & $9.42 \%$ \\
\hline Eshop administration & $15 \%$ & $13.55 \%$ \\
\hline Accounting & $20 \%$ & $16.47 \%$ \\
\hline Strategic study & $10 \%$ & $8.75 \%$ \\
\hline $\begin{array}{l}\text { Analysis of the information system } \\
\text { used in the course }\end{array}$ & $10 \%$ & $9.12 \%$ \\
\hline
\end{tabular}

Source: own contribution

During each year of Electronic Information Systems course teaching, surveys to gather feedback on the course are conducted. The survey is conducted after the course completion in each curse 


\section{Pal'ová et al. / Advances in Science, Technology and Engineering Systems Journal Vol. 5, No. 1, $346-354$ (2020)}

iteration. Investigated participants' opinions on the EIS course are divided between the parts such as starting-up the business, epayments, communication with public administration authorities and e-commerce. The students' answers also provide suggestions for improvement of the education process in the course. The survey completion was mandatory for all participants of the course. In the most recent survey, 117 completed questionnaires were gathered.

The main results of the recently conducted survey can be summarized as follows:

- Almost $95 \%$ of students reported, that they acquired significant experience with establishing and management of the start-up company during the EIS course.

- Over $85 \%$ percent of respondents adduced gaining new information and experience with the process of the business establishment in accordance with the valid local legislation.

- $\quad$ Over $98 \%$ percent of participants agreed that obtaining practical experience with e-communication with virtual public administration authorities using the electronic registry was instructive.

- Almost 95\% of the respondents highlighted the use of the digital signature in electronic communication with public administration authorities as valuable experience.

- Above $42 \%$ of the course participants indicated that the creation of the business plan of their virtual company was beneficial for them. All of the students already had experience with writing the business plan during previous years of their studies.

- $\quad$ More than $29 \%$ of students adduced that creating their company's website company was beneficial, even though they already had created a website before in other courses.

- Setting-up and managing their firm's e-shop was a significant experience for more than $78 \%$ of participants. Mainly, the operation of an e-shop from the administrator's side was highlighted by the participants.

- Almost $63 \%$ of students appreciated the possibility to try out to keep an accounting of their firms. Especially, the experience in the first business period accounting was emphasized.

- Approximately $65 \%$ of respondents also welcomed the preparation of a strategic plan of their firms for the upcoming years (beyond the horizon of the ongoing course).

- Most of the course participants (93\%) evaluated the whole course of Electronic Information Systems very positively in general. Moreover, they appreciated the opportunity to practically experience the entrepreneurial processes within the virtual laboratory of electronic entrepreneurship.

In general, it can be concluded, that both described courses "Marketing Tools for the Presentation and Evaluation of Business Ideas" and "Economic Information Systems" stimulated the higher activity of the students. Furthermore, the course participants also often discussed the various issues and topics during the course lessons in order to solve the problems with projects. In spite of short time of the course duration (three months), students handled the product development, the creation of the website, to preparation and execution of marketing campaign and analysis of the data collected (as for the "Marketing Tools for the Presentation and Evaluation of Business Ideas" course) and experience the first year of existence of virtual start-up company (as for the "Economic Information Systems" course).

In both cases, students welcomed this opportunity and highly evaluated the course's benefits. The usage of ICT tools and virtual laboratory for entrepreneurial education appears to be beneficial according to our results. Also, the participants' practical experience with the projects is among the most important outcomes of both courses.

In connection with the EntreComp Framework, students achieved competencies from the parts of "Ideas \& Opportunities" (especially vision, creativity, evaluation of ideas and sustainable thinking), "Resources" (financial and economic literacy, mobilizing resources) and "Into Action" (learning through experience, working with others, planning and management, coping with ambiguity, uncertainty, and risk) [10].

\section{Conclusion}

Despite different actions supporting the entrepreneurship from the EU like "Funding opportunities" [41], "Erasmus for Young Entrepreneurs" [42] or "EU Startup Services" [43], it is not trivial for young people to start their own business. The business sector is challenging and changing at a rapid pace and it is hard to enter this world without any previous knowledge and skills.

In [44], 34\% of self-employed respondents stated the need to take an entrepreneurship course before starting up their own business, because they perceive an insufficiency of experience and skills necessary to ensure the sustainability of the business in the labor market. At the same time, from this research follows, that just less than half of EU citizens perceive that their education gave them the know-how and the skills to enable them to run a business $(41 \%)$ or allowed them to understand the role of entrepreneurs in society $(47 \%)$ [44].

This was the motivation to innovate courses in a way to implement most of the missing entrepreneurial skills into the education process.

The course of "Economic Information Systems" allows participants to acquire practical entrepreneurial experience in the field of e-commerce using the virtual laboratory of electronic entrepreneurship. Students gained practical experience with setting-up business according to the Slovak Republic legislation. Moreover, they experienced the usage of digital signature and the electronic registry in communication, the creation of the business plan, the preparation of the company's website with implemented e-shop and its administration. Finally, the course participants tried to keep accounting and to create a strategic plan for the future periods of their virtual firms. The use of the virtual laboratory for the purposes of entrepreneurial education is unique in educational processes of Slovak universities.

The course of "Marketing Tools for the Presentation and Evaluation of Business Ideas" allows students to experience practical education from the introduction of a new product and its marketing. Within the course, its participants solve the problems of developing the product, product's fit to the market, marketing analytics, which allows them to experience the launch of the 
business supported by ICT tools. The students have to come with a business idea and confirm its viability. Furthermore, they gain theoretical and practical knowledge in business models, online marketing, web design, and data analysis. Moreover, the course participants have to design a web page, which is also used for collecting data for Google Analytics. Students also gain practical experience with network marketing, WordPress, Google Ads, Google Trends, Google Tag Manager, Google Market Finder.

In both courses, students highly evaluated the courses' benefits and the practical experience gained during the participation in the courses. By graduating described courses, participants got a chance to achieve or improve their knowledge and skills listed in EntreComp Framework. Step by step, by taking part in the time and solving the semestral projects, they built up the particular competencies needed in the business sector, such as the ability to be innovative and creative and define the problems and find suitable solutions. The usage of virtual laboratory and ProjectBased Learning for entrepreneurial education appears to be beneficial according to results acquired.

Conjunction of these courses create educational synergies for better preparation of students for their possible entrepreneurial future. Passing these courses increases chances of successful selfemployment of courses' graduates or even the creation of new work-positions for the others as they might start-up new businesses in real economic environment. It also might lower the unemployment rate in given economy, what is closely connected to the objectives stated in Europe 2020 strategy [7].

\section{Conflict of Interest}

The authors declare no conflict of interest.

\section{Acknowledgment}

This contribution was supported by the national project "Decision Support Systems and Business Intelligence within Network Economy" (Contract No. 1/0201/19) funded by Grant Agency for Science; Ministry of Education, Science, Research and Sport of the Slovak Republic.

\section{References}

[1] L. Kakalejčík, D. Pal'ová, "Enhancement of students' skills via projectbased learning" in MIPRO 2019: 42nd international convention. Croatian Society for Information and Communication Technology, Electronics and Microelectronics, 769-774, Rijeka, Croatia, 2019. http://dx.doi.org/10.23919/MIPRO.2019.8756958

[2] J. Gerdin, G. Linton, "Contingency fit(s) in entrepreneurship research: uses and usability", Örebro University School of Business, 2016.

[3] K. Harris, Education and Knowledge: the structured misrepresentation of reality, Routledge, 2016.

[4] P. Thiel, B. Masters, Zero to One: Notes on Startups, or How to Build the Future, New York: Crown Business, 2014.

[5] M. Vejačka, "Electronic commerce entrepreneurship education using virtual laboratory" in MIPRO 2019: 42nd international convention. Croatian Society for Information and Communication Technology, Electronics and Microelectronics, 670-675, Rijeka, Croatia, 2019. http://dx.doi.org/10.23919/MIPRO.2019.8757070.

[6] Statista, "Youth unemployment rate in EU member states as of December 2018", Statista, 2018.

[7] European Commission, "EUROPE2020: A European strategy for smart, sustainable and inclusive growth", European Commission, 2010.

[8] Council of the European Union, "Council conclusions on entrepreneurship in education and training", Education, Youth, Culture and Sport Council meeting, Council of the European Union, 2014.

[9] European Commission, "Analytical Highlight Focus On Entrepreneurial skills”, EU Skills Panorama, European Commission, 2015.
[10] European Commission, "EntreComp: The Entrepreneurship Competence Framework", JRC Science for Policy Report, European Commission, 2016.

[11] D. E. McCorkle, J. M. Payan, J. Reardon, N. D. Kling, "Perceptions and reality: Creativity in the marketing classroom" Journal of Marketing Education, SAGE Publications, Thousand Oaks, Canada, 29(3), 254-261, 2007. http://dx.doi.org/10.1177/0273475307306892

[12] J. Wiklund, S. Dean, "Entrepreneurial Orientation and Small Business Performance: a Configurational Approach" Journal of Business Venturing, 20, 71-91, 2005. http://dx.doi.org/10.1016/j.jbusvent.2004.01.001

[13] .G. T. Lumpkin, G. G. Dess, "Linking two Dimensions of Entrepreneurial Orientation to Firm Performance: The Moderating Role of Environment and Industry Life Cycle" Journal of Business Venturing, 16, 429-451, 2001.

[14] Institute of Entrepreneurship Development, "4 Important Skills for Young Entrepreneurs", Institute of Entrepreneurship Development, 2017.

[15] J. S. Brown, "Learning in the Digital Age" The Internet \& the University: Forum 2001, 65-91. 2001.

[16] D.F. Roberts, U.G. Foehr, V.Rideout, "Generation M: Media in the Lives of 8-18 Year-olds", A Kaiser Family Foundation Study, 2005.

[17] International Education Advisory Board, "Learning in the 21st Century: Teaching Today's Students on Their Terms", International Education Advisory Board, 2007.

[18] Buck Institute for Education, "Gold Standard PBL: Essential Project Design Elements", PBL works, Buck Institute for Education, 2018.

[19] S. Boss, "Project-Based Learning: A Short History", Edutopia, 2011.

[20] Buck Institute for Education, "What is PBL?", PBL works, Buck Institute for Education, 2019

[21] C. E. Hmelo-Silver, "Problem-based learning: What and how do students learn?" Educational Psychology Review, 16(3), 235-266, 2004. http://dx.doi.org/10.1023/B:EDPR.0000034022.16470.f3

[22] H. G. Schmidt, S. M. M. Loyens, T. Van Gog, F. Paas, "Problem-based learning is compatible with human cognitive architecture: Commentary on Kirschner, Sweller, and Clark (2006)" Educational Psychologist 42(2), 9197, 2007.

[23] M. J. Sousa, M. do R. Almeida, "Entrepreneurial Skills Development" in Recent Advances in Applied Economics, Lisbon, Portugal, 2014.

[24] R. Klamma, M. Spaniol, D. Renzel, "Virtual entrepreneurship lab 2.0: sharing entrepreneurial knowledge by non-linear story-telling" Journal of Universal Knowledge, 1(3), 174-198, 2006.

[25] B. S. Wästberg, T. Eriksson, G. Karlsson, M. Sunnerstam, M. Axelsson, M. Billger, "Design considerations for virtual laboratories: A comparative study of two virtual laboratories for learning about gas solubility and colour appearance" Education and Information Technologies, 24(3), 2059-2080, 2019.

[26] M.. Koehler, "What is technological pedagogical content knowledge (TPACK)?" Journal of Education, 193(3), 13-19, 2013. http://dx.doi.org/10.1177/002205741319300303

[27] S. L. Bretz, M. Fay, L .B. Bruck, M. H. Towns, "What faculty interviews reveal about meaningful learning in the undergraduate chemistry laboratory" Journal of Chemical Education, 90(3), 281-288, 2013. http://dx.doi.org/10.1021/ed300384r

[28] L. B. Bruck, M. Towns, S. L. Bretz, "Faculty perspectives of undergraduate chemistry laboratory: goals and obstacles to success" Journal of Chemical Education, 87(12), 1416-1424, 2010. http://dx.doi.org/10.1021/ed900002d

[29] A. H., Johnstone, A. Al-Shuaili, "Learning in the laboratory; some thoughts from the literature" University Chemistry Education, 5(2), 42-51, 2001.

[30] D I. Lewis, "The pedagogical benefits and pitfalls of virtual tools for teaching and learning laboratory practices in the biological sciences" The Higher Education Academy: STEM, 2014.

[31] K. Achuthan, V. K. Kolil, S. Diwakar, "Using virtual laboratories in chemistry classrooms as interactive tools towards modifying alternate conceptions in molecular symmetry" Education and Information Technologies, 23, 2499-2515, 2018. https://doi.org/10.1007/s10639-018$9727-1$.

[32] A. Hakim, A. Liliasari, A. Kadarohman, Y. M. Syah, "Effects of the natural product mini project laboratory on the students' conceptual understanding" Journal of Turkish Science Education (TUSED), 13(2), 27-36, 2016.

[33] N. Patel, "90\% Of Startups Fail: Here's What You Need To Know About The 10\%", Forbes, 2015.

[34] F. R. da Silva, R. Fabrício, P.R. da Silva, N.V. Galegale, G. K. Kabane, "Why technology-based startups fail? An IT management approach" in Production and Operations Management Society, POMS 26th Annual Conference, Washington, D.C., USA, 2015. 
[35] X. Wang, H. Edison, S. S. Bajwa, C. Giardino, P. Abrahamsson, "Key challenges in software startups across life cycle stages" in International Conference on Agile Software Development, Springer International Publishing, 169, 2016. http://dx.doi.org/10.1007/978-3-319-33515-5_14

[36] C. Giardino, S. S. Bajwa, X. Wang, P. Abrahamsson., "Key challenges in early-stage software startups" in International Conference on Agile Software Development, Springer, Cham, Switzerland, 2015. http://dx.doi.org/10.1007/978-3-319-18612-2_5

[37] N. Granitz, P. Leyland, "Teaching about marketing and teaching marketing with innovative technology: Introduction to the special edition" Journal of Marketing Education, 33(2), 127-130, 2011. http://dx.doi.org/10.1177/0273475311410844

[38] R. W. Price, Roadmap To Entrepreneurial Success Powerful Strategies for Building a High-Profit Business, Global Entrepreneurship Institute, AMACOM Books, American Management Association, 2004.

[39] E. Turban, D. King, J.K. Lee, T.P. Liang, D.C. Turban, "Electronic commerce" Prentice Hall Press Upper Saddle, NJ, USA, 2015. http://dx.doi.org/10.1007/978-3-319-10091-3

[40] V. Venkatesh, J. Y. L. Thong, F. K. Y. Chan, P. J. H. Hu, "Managing citizens' uncertainty in e-government services: the mediating and moderating roles of transparency and trust" Information Systems Research, 27(1), 1-218, 2016. http://dx.doi.org/10.1287/isre.2015.0612

[41] European Commission, "Funding opportunities for small businesses", European Commission, 2015.

[42] European Commission, "Erasmus for Young Entrepreneurs", European Commission, 2019.

[43] European commission, "EU Startup Services", European Commission, 2017.

[44] European Commission, "Entrepreneurship in the EU and beyond", Eurobarometer, European Commission, 2010. 